\title{
(Association of Methylenetetrahydrofolate Reductase (MTHFR) A1298C gene polymorphism with Breast Cancer in Egyptian women)
}

Besheer El-Sayed Bayomy ${ }^{a}$, Afaf Mohammed El-said ${ }^{\mathrm{b}}$, Noha Mohamed Said ${ }^{\mathrm{c}}$, and Mona Mohammed Ibrahim ${ }^{b^{*}}$

${ }^{a}$ Chemistry Department, Faculty of science, Zagazig University, Zagazig, Egypt

${ }^{b}$ Children Hospital, faculty of Medicine-Mansoura University, Mansoura, Egypt

${ }^{c}$ Biochemistry Division, Chemistry Department, Faculty of science, Zagazig University, Zagazig, Egypt

\begin{tabular}{l}
\hline A R T I C L E I N F O \\
\hline Article history: \\
Received \\
Accepted \\
Available online \\
Key words: \\
polymorphism- RFLP- \\
PCR- MTHFR- breast \\
cancer
\end{tabular}

Abstract

Bachground: Methlenetetrahydrofolate reductase (MTHFR) is one of the most important enzymes for folate metabolism. This enzyme is mapped on chromosome 1, The methylene tetra hydro folate reductase (MTHFR) gene is a polymorphic gene involved in folate metabolism, DNA biosynthesis, methylation and genomic integrity in actively dividing cells. The MTHFR A1298C polymorphism is likely to play an important role in the susceptibility to breast cancer. Objectives: In this case-control study, we examin the role of MTHFR A1298C polymorphism in breast cancer patients. Methods: We examined the MTHFR A1298C polymorphism in 47 women with breast cancer and 42 healthy women using PCRRFLP method. Results: The alleles frequency of the MTHFR A1298C were $41.5 \%$ and $58.5 \%$ for A and C alleles in the breast cancer cases and $47.6 \%$ and $52.4 \%$ in the controls respectively. The genotypes frequency of the MTHFR A1298C for AA, CC and AC in breast cancer patients were $14.9 \%, 31.9 \%$ and $53.2 \%$ and in control subjects were $9.5 \%, 14.3 \%$ and $76.2 \%$ respectively . There is increased risk for breast cancer under 3 models (Allellic $\mathrm{C}$ vs.A) ,Homozygote ( $\mathrm{CC}$ vs.AA) and Recessive(CC vs.AC+AA) [OR 1.282,1.429 and 2.813 respectively] . conclusion: our data suggest that the MTHFR A1298C alleles and genotypes may play arole in breast cancer susceptibility but not astrong risk factor for women with breast cancer.

Conclusions: Our findings suggest a possible association between IL-10(-1082 G/A) promoter polymorphism and HCV infection, which may confer a higher risk for developing HCV infection.

Corresponding Author: Fax: +20 552308218, E-mail address: dr.monaelhadi@yahoo.com 


\section{INTRODUCTION}

Worldwide, breast cancer comprises $10.4 \%$ of all cancer incidence among women, making it the second most common type of non-skin cancer (after lung cancer) and the fifth most common cause of cancer death[1]. In 2004, breast cancer caused 519,000 deaths worldwide (7\% of cancer deaths; almost $1 \%$ of all deaths). In Egypt, it is the most common cancer among women, representing $18.9 \%$ of total cancer cases [2].

Most known risk factors for breast cancer can be linked to hazardous effects of hormonal exposures, although other risk factors such as female ( $1 \%$ male), aging, relative (mother or sister), menstrual history (early onset or late menopause), child birth after the age of 30, exogenous estrogen, radiation exposure and obesity are also relevant in some populations. Approximately $15 \%$ of all breast cancer cases can be attributed to familial and genetic influences [3].

Two common functional polymorphisms of MTHFR gene are known as the following : a common polymorphism exists in the gene encoding the catalytic domain of the methylenetetrahydrofolate reductase (MTHFR) in which a $\mathrm{C}-\mathrm{T}$ substitution (cytosine to thymidine) at the 677 position results in the replacement of alanine into valine at position 222 of the protein and the other polymorphism is the A1298C, which results in a substitution of glutamate with alanine at codon 429 [4].

This work was conducted to assess the role of single nucleotide polymorphisms in MTHFR which is a key enzyme in the folate metabolism pathway at position A1298C in breast cancer Susceptibility in Egyptian women.

\section{Subjects and methods}

\section{Patients and controls}

The present study included 47 adult female of breast cancer patients and 42 female healthy unrelated subjects with a negative family history of tumor disorders. The patient and healthy female were chosen from hospitals of Zagazig and mansoura Universities in the period from May 2012 until December 2014, The detailed history of the voulenteers was known with the consent of them . For each case, history, full clinical examination, routine laboratory investigations and specific laboratory investigations (detection of MTHFR gene polymorphism at position A1298C) were done.

\section{Sample collection}

Samples were collected by taking 3 $\mathrm{ml}$ of venous blood from all patients and controls on EDTA for analysis of genepolymorphisms by PCR. Another sample of $5 \mathrm{ml}$ venous blood was taken for assessment of serum laboratory tests such as CA15.3.

All tests were two sided. $\mathrm{p}<0.05$ was considered statistically significant $(\mathrm{S})$, $\mathrm{p}<0.01$ was considered highly statistically significant (HS), and $\mathrm{p} \geq 0.05$ was considered non statistically significant (NS).

\section{Detection of MTHFR A1298T polymorphism}

DNA should be extracted then it analyzed by PCR , followed by gel electrophoresis for detection of A1298C MTHFR gene mutation (polymorphism).

\section{DNA Extraction:}

DNA was isolated from whole blood according to the Generation DNA Purification capture column kit supplied by (Fermentas, K 0721,U.S.A.). 


\section{Genotyping using (PCR- RFLP) conditions:}

DNA isolated from patients and control samples was used for genotyping these samples using (PCR-RFLP).PCR reactions were performed using master mix solution, specific primers and DNA template in a final volume of $25 \mathrm{ul}$.

\section{Forward primer:}

5'CTTCTACCTGAAGAGCAAGTC-3 and Reverse primer: $5^{\prime}$

\section{CATGTCCACAGCATGGAG-3'.}

PCR Program was done in 37 cycles, 1 cycle of Pre denaturation at $95^{\circ} \mathrm{C}$ for 5 minutes , 35 cycles of (Denaturation $95^{\circ} \mathrm{C}$ for 1 minutes, annealing at $61{ }^{\circ} \mathrm{C}$ for 1 minutes, extension $72^{\circ} \mathrm{C}$ for 1 minutes), and 1 cycle of final extension $72^{\circ} \mathrm{C}$ for 7 minutes. The PCR product size is $256 \mathrm{bp}$ and it was digested with the digestive restriction enzyme MobII (New England Biolabs, U.S.A.). This enzyme is used under Incubation temperature of $37^{\circ} \mathrm{C}$, the Recognition Sequence is 5'..GAAGA(N)8 $\boldsymbol{\nabla} . .3$ '.

Gel electrophoresis: the Size of digested fragments of PCR product is $176,30,28,22$ for A allele and 204,30,22,30 for C allele and this is showed in Fig (1).

\section{Statistical analysis}

All data were analyzed using SPSS 18.0 for windows (SPSS Inc., Chicago, IL, USA) Continuous variables were expressed as the mean \pm SD \& median (range), and the categorical variables were expressed as a number(percentage).

Continuous variables were checked for normality by using Shapiro-Wilk test. Mann Whitney U test was used to compare two groups of non-normally distributed data. Kraskall Wallis $\mathrm{H}$ test was used to compare more than two groups of non- normally distributed data. Percent of categorical variables were compared using the Chi-square $(\chi 2)$ test.

\section{RESULTS}

Methylenetetrahydrofolate

reductase gene polymorphism is a good marker in breast cancer susceptibility. There was a non-significant difference in breast cancer patients and the control subjects regarding distribution of MTHFR (A1298C) genotype and allele frequencies with the following frequencies and $\mathrm{P}$-value (Sig) $14.9 \%$ for AA, $31.9 \%$ for CC,53.2\% for $\mathrm{CC}$ in breast cancer patients and $9.5 \%$, $14,3 \%$ and $76.2 \%$ in control subjects with $\mathrm{P}$-value (0.072), $41.5 \%$ for $\mathrm{A}$ and $58.5 \%$ for $\mathrm{C}$ in breast cancer patients and $47.6 \%$, $52.4 \%$ in control subjects with P-value (0.411) respectively as in table (1)and (2).

There were non-significant associations between the MTHFR (A1298C) gene polymorphism models and risk of breast cancer with P-value $0.4110 .652,0.229,0.442$ and 0.051 as in table ( 3 ). There were non-significant associations between the MTHFR (A1298C) gene polymorphism and clinical characteristics $(p>0.05)$ as in table (4). Finally, there was statistically a high significant difference in breast cancer patients and control groups regarding the levels of CA15-3 ( $p<0.001)$ as in table (5) and non-significant associations between genotypes and CA15-3 level in breast cancer patients $(\mathrm{p}>0.05)$ as in table (6) .

\section{DISCUSSION}

Methylenetetrahydrofolate

reductase ( MTHFR) is a key enzyme residing at a critical metabolic branch point in folate metabolism; it catalyzes the irreversible conversion of 5,10methylenetetrahydrofolate $\quad(5,10$ methyleneTHF) into 5methyltetrahydrofolate (5-methylTHF), which directs the folate pool towards 
homocysteine remethylation into methionine at the expense of DNA and RNA biosynthesis [5].Two common polymorphisms have been described in the MTHFR gen both single nucleotide substitutions resulting in amino acid changes (C677T !Ala222Val and A1298C !Glu429Ala)[6,7].

This work was conducted to assess the role of single nucleotide polymorphisms in MTHFR which is a key enzyme in the folate metabolism pathway at position A1298C in breast cancer Susceptibility in Egyptian women. Indeed, numerous epidemiological studies have examined the relationship between MTHFR polymorphisms and cancer risk but have generated conflicting results. The results from previous association studies on the MTHFR polymorphisms and breast cancer risk are also inconsistent.

The present study included 47 adult female patients. For each case, history, full clinical examination, routine laboratory investigations (including glucose, creatinine, calcium, phosphorus, cholesterol, uric acid, bilirubin, total protein, albumin, albumin transferese, AST, Alkaline phosphatase, $\mathrm{Na}, \mathrm{K}$, CBC,CEA,CA15.3 and double strand DNA) and specific laboratory investigations (detection of MTHFR enzyme polymorphism at position A1298C is done. For comparison, the study included another control sample taken in the form of 42 female healthy unrelated subjects with a negative family history of tumor disorders. Several clinical studies have reported that the MTHFR C677T variants are associated with an increased risk of early-onset breast cancer before the age of 40 [8], breast carcinoma in pre-menopausal women $[9,10]$ . Whereas, several studies have reported that the MTHFR 1298CC genotype[11,12] and MTHFR compound heterozygosity (677CT and 1298AC)[12] were associated with a reduced risk of developing breast cancer. Nevertheless, lack of an association of MTHFR polymorphisms with breast cancer was also observed in a number of epidemiological studies[13,14]. In this study, a significantly decreased risk for breast cancer was observed in subjects who carried the compound MTHFR variant genotypes at 1298 loci.

Our results showed a non-significant difference in breast cancer patients and the control subjects regarding distribution of MTHFR A1298C genotype and allele frequencies.

There were also non-significant associations between the MTHFR A1298C gene polymorphism models and risk of breast cancer.

Castro and his collagues (2004) [15] investigated the effect of the A1298C MTHFR polymorphism on leukocyte genomic DNA methylation status in 96 healthy unrelated white Portuguese subjects. The authors found that mutation when homozygous were associated with decreased DNA methylation status, although the effect was slightly less pronounced for the A1298C transversion. The authors suggested that the 1298CC MTHFR genotype, independently of folate availability, and the 677TT MTHFR genotype with concomitant low folate levels, might be potential risk factors for disease states associated with DNA hypomethylation status.

Kang and his coworkers (2005) [16] found that the effect of this polymorphism is not strong as seen with MTHFR C677T, consistent with its less severe impact on enzyme activity; this polymorphism is associated with increased or unchanged risk of breast cancer, and unchanged risk of cervical cancer. 
Campbell and his collagues (2002) [8] analyzed the C677T polymorphism in a case-control study of 335 women with breast cancer and 233 controls. They concluded that the low activity C677T (valine) genotype of MTHFR may increase the risk of early onset breast cancer.

Qi and his collagues (2010) [17] reported that in the subgroup analysis by ethnicity, significantly increased risk was found in East Asian population but not in Caucasian population; in the subgroup analysis by menopausal status, no statistically significant association was found. With respect to A1298C polymorphism, no significant association with breast cancer risk was demonstrated in overall, ethnicity- and menopausal statusbased population.

Our results showed statistically a high significant difference in breast cancer patients and control groups regarding the levels of CA15-3 and non-significant associations between genotypes and CA153 level in breast cancer patients.

In summary, the present study findings provide support for an important role of folate metabolism in breast tumorigenesis., our data suggest that the MTHFR A1298C alleles and genotypes may play arole in breast cancer susceptibility but not astrong risk factor for women with breast cancer.

\section{REFERENCES}

1. World Cancer Report. Retrieved (2010):05-08.

2. Yang W.I., Park B.W., and Lee K.S., (2005) :Clinicopathological characteristics of mucinous carcinoma of the breast in Korea: comparison with invasive ductal carcinoma-not yyyyotherwise specified. J Korean Med Sci; 25(3): 361-368.

3. Shapiro, S., Dietel, M., Lewis M.A., and (2012): Hormone replacement therapy: Pathobiological aspects of hormone sensitivecancers in women relevant to epidemiological studies on HRT: a mini review. Human Reproduction; 20:2052-60.

4. Ueland P.M., Hustad S., Schneede J., Refsum H., Vollset S.E., (2001) : Biological and clinical implications of the MTHFR C677T polymorphism. Trends PharmacolSci 22:195201. PubMed Abstract | Publisher Full Text.

5. Bailey L.B., and Gregory J.F., (1999): Polymorphisms of methylenetetrahydrofolate reductase and other enzymes: metabolic significance, risks and impact on folate requirement. J. Nutr; 129: 919-922.

6. Goyette P., Pai A., Milos R., Frosst P., Tran P., Chen Z., Chan M., and Rozen R., (1998): Gene structure of human and mouse methylenetetrahydrofolate reductase (MTHFR). Mamm. Genome ; 9: 652-656.

7. Kim Y.I., (2000)

Methylenetetrahydrofolate reductase polymorphisms, folate, and cancer risk: a paradigm of gene-nutrient interactions in carcinogenesis. Nutr. Rev;58: 205-209.

8. Campbell I.G., Baxter S.W., Eccles D.M., and Choong D.Y., (2002):

Methylenetetrahy-

9. drofolate reductase polymorphism and susceptibility to breast cancer. Breast Cancer Res., 4, R14.

10. Ergul E., Sazci A., Utkan Z., and Canturk N.E., (2003)

:Polymorphisms in the MTHFR gene are associated with breast cancer. Tumor Biol; 24: 286- 
290.Gershoni-Baruch R., Dagan E., Israeli D., Kasinetz L., Kadouri E., . 11. Semenza J.C., Delfino R.J., Ziogas A., and Anton-Culver H., (2003): Breast cancer risk and methylenetetrahydrofolate reductase polymorphisms. Breast Cancer Res. Treat; 77: 217-223.

12. Chen J., Gammon M.D., Chan W., Palomeque C., Wetmur J.G., Kabat G.C., Teitelbaum S.L., Britton J.A., Terry M.B., Neugut A.I., and Santella R.M., (2005): One-carbon metabolism, MTHFR polymorphism and risk of breast cancer. Cancer Res; 65: 1606-1614.

13. Sharp L., Little J., Schofield A.C., Pavlidou E., Cotton S.C., Miedzybrodzka Z., Baird J.O.C., Haites N.E., and Grubb D.A., (2002): Folate and breast cancer: the role of polymorphisms in methylenetetrahydrofolate reductase (MTHFR). Cancer Lett; 181: 65-71.

14. Langsenlehner U., Krippl P., Renner W., Yazdani-Biuki B., Wolf C.T., Wascher T.C., Paulweber B., Weitzer W., and Samonigg H., (2003): The common 677C>T gene polymorphism of methylenetetrahydrofolate reductase gene is not associated with breast cancer risk. Breast Cancer Res. Treat; 81: 169-172.

15. Justenhoven C., Hamann U., Pierl C.B., Rabstein S., Pesch B., Harth
V., Baisch C., Vollmert C., Illig T., Bruning T., KoY., and Brauch H., (2005) :One-carbon metabolism and breast cancer risk: No association of MTHFR, MTR, and TYMS polymorphisms in the GENICA Study from Germany. Cancer Epidemiol. Biomarkers Prev;14:3015-3018.

16. Castro R., Rivera I., Ravasco P., Camilo ME., Jakobs C., Blom HJ., de Almeida IT., (2004): 5,10-

Methylenetetrahydrofolate reductase (MTHFR) 677C-T and 1298A-C mutations are associated with DNA hypomethylation (Letter). J Med Genet; 41: 454-458.

17. Kang S., Kim J.W., Kang G.H, Park N.H., Song Y.S., (2005):

Polymorphism in folate and methionine - metabolizing enzyme and aberrant CPG island hypermethylation in uterine cervical cancer. GynecolOncol; 96: 173-180.

18. Qi X., Ma X., Yang X., et al. (2010): Methylene tetrahydrofolate reductase polymorphis- $\mathrm{ms}$ and breast cancer risk: A meta-analysis from 41 studies with 16,480 cases and 22,388 controls. Breast Cancer Research and Treatment; 123(2): 499-506. 


\begin{tabular}{|c|c|c|c|c|c|c|}
\hline $\mathbf{A C}+\mathbf{A A}$ & 32 & $68.1 \%$ & 36 & $85.7 \%$ & \multirow{2}{*}{3.824} & 0.051 \\
\hline$\overline{C C}$ & 15 & $31.9 \%$ & 6 & $14.3 \%$ & & (NS) \\
\hline
\end{tabular}

AA: wild genotype, $\mathrm{CC}+\mathrm{AC}$ : mutantcarrier genotypes, $\mathrm{CC}$ : mutant homozygote, AC: mutant heterozygote. $\chi^{2}$ Chi-square test for independence. $\mathbf{p}<0.05$ is significant. Sig.: significance.

Table (2): Distribution of MTHFR (A1298C) allele frequencies in breast cancer patients $(n=47)$ and the control subjects $(n=42)$.

\begin{tabular}{|c|c|c|c|c|c|c|}
\hline \multirow[t]{2}{*}{ Alleles } & \multicolumn{2}{|c|}{$\begin{array}{l}\text { Breast cancer } \\
\text { patients loci } \\
\quad(n=94)\end{array}$} & \multicolumn{2}{|c|}{$\begin{array}{c}\text { Control } \\
\text { subjects loci } \\
\quad(n=84)\end{array}$} & \multirow[t]{2}{*}{$\chi^{2}$} & \multirow[t]{2}{*}{$\begin{array}{c}\text { p-value } \\
\text { (Sig.) }\end{array}$} \\
\hline & No. & $\%$ & No. & $\%$ & & \\
\hline$\overline{\mathbf{A}}$ & 39 & $41.5 \%$ & 40 & $47.6 \%$ & \multirow{2}{*}{0.675} & 0.411 \\
\hline $\mathbf{C}$ & 55 & $58.5 \%$ & 44 & $52.4 \%$ & & $(\mathrm{NS})$ \\
\hline
\end{tabular}

$\chi^{2}$ Chi-square test for independence. $\mathbf{p}<0.05$ is significant. Sig.: significance.

Table (3): Association between the MTHFR (A1298 C) gene polymorphism and risk of breast cancer.

\begin{tabular}{|c|c|c|c|}
\hline Models & OR $(95 \% \mathrm{CI})$ & $\chi^{2}$ & p-value (Sig.) \\
\hline Allelic (C vs. A) & $1.282(0.709-2.320)$ & 0.675 & $0.411(\mathrm{NS})$ \\
\hline Homozygote (CC vs. AA) & $1.429(0.303-6.737)$ & 0.204 & $0.652(\mathrm{NS})$ \\
\hline $\begin{array}{c}\text { Heterozygote (AC vs. } \\
\text { AA) }\end{array}$ & $0.446(0.117-1.697)$ & 1.448 & 0.229 (NS) \\
\hline $\begin{array}{c}\text { Dominant }(\mathrm{CC}+\mathrm{AC} \text { vs. } \\
\text { AA })\end{array}$ & $0.602(0.163-2.221)$ & 0.590 & $0.442(\mathrm{NS})$ \\
\hline
\end{tabular}




\begin{tabular}{c|c|c|c}
$\begin{array}{c}\text { Recessive (CC vs. } \\
\text { AC+AA) }\end{array}$ & $2.813(0.975-8.116)$ & 3.824 & $0.051(\mathrm{NS})$ \\
\hline
\end{tabular}

OR: Odds ratio. $95 \%$ CI: $95 \%$ confidence interval. $\chi^{2}$ Chi-square test for independence. $\mathbf{p}<0.05$ is significant. Sig.: significance.

Table (4): Association of MTHFR (A1298C) polymorphism with clinical characteristics.

\begin{tabular}{|c|c|c|c|c|c|c|}
\hline \multirow{2}{*}{$\begin{array}{c}\text { Clinical } \\
\text { characteristics }\end{array}$} & \multicolumn{2}{|c|}{$(n=40)$} & \multicolumn{2}{|c|}{$(n=7)$} & \multirow[t]{2}{*}{$\chi^{2}$} & \multirow{2}{*}{$\begin{array}{c}\text { p-value } \\
\text { (Sig.) }\end{array}$} \\
\hline & No. & $\%$ & No. & $\%$ & & \\
\hline Age & & & & & & \\
\hline$\leq 50$ & 32 & $80 \%$ & 6 & $85.7 \%$ & \multirow{2}{*}{0.126} & 0.723 \\
\hline $51-60$ & 8 & $20 \%$ & 1 & $14.3 \%$ & & $(\mathrm{NS})$ \\
\hline \multicolumn{7}{|l|}{ Tumor size } \\
\hline $\mathrm{T} 2$ & 40 & $100 \%$ & 7 & $100 \%$ & --- & --- \\
\hline \multicolumn{7}{|l|}{ Histological Type } \\
\hline DCIS & 7 & $17.5 \%$ & 1 & $14.3 \%$ & \multirow{2}{*}{0.044} & 0.835 \\
\hline IDC & 33 & $82.5 \%$ & 6 & $85.7 \%$ & & (NS) \\
\hline \multicolumn{7}{|l|}{ Histological grade } \\
\hline II & 9 & $22.5 \%$ & 1 & $14.3 \%$ & \multirow{2}{*}{0.240} & 0.624 \\
\hline III & 31 & $77.5 \%$ & 6 & $85.7 \%$ & & (NS) \\
\hline \multicolumn{7}{|l|}{$\underline{\text { Stage }}$} \\
\hline Stage 0 & 7 & $17.5 \%$ & 1 & $14.3 \%$ & \multirow{2}{*}{0.044} & 0.835 \\
\hline Stage II & 33 & $82.5 \%$ & 6 & $85.7 \%$ & & $(\mathrm{NS})$ \\
\hline
\end{tabular}


Table (5): The levels of CA15-3 in breast cancer patients and control groups.

\begin{tabular}{|c|c|c|c|c|}
\hline CA15-3 (U/ml) & $\begin{array}{l}\text { Breast cancer } \\
\text { patients } \\
\quad(n=105)\end{array}$ & $\begin{array}{l}\text { Control } \\
\text { subjects } \\
(n=42)\end{array}$ & $\mathbf{Z}$ & $\begin{array}{c}\text { p-value } \\
\text { (Sig.) }\end{array}$ \\
\hline Mean \pm SD & $63.89 \pm 177.85$ & $12.93 \pm 1.77$ & \multirow{2}{*}{-3.510} & \multirow{2}{*}{$\begin{array}{c}<0.001 \\
(\mathrm{HS})\end{array}$} \\
\hline Median (Range) & $19.7(4-1167)$ & $12.5(10-18)$ & & \\
\hline
\end{tabular}

ZMann Whitney U test. $\mathbf{p}<0.05$ is significant. Sig.: significance.

Table (6): Association between CA15-3 level and genotypes in breast cancer patients.

\begin{tabular}{|c|c|c|c|c|c|}
\hline \multirow{2}{*}{ Genotype } & \multirow{2}{*}{$\mathbf{N}$} & \multicolumn{2}{|c|}{ CA15-3 (U/ml) } & \multirow{2}{*}{$\chi^{2}$} & \multirow{2}{*}{$\begin{array}{c}\text { p-value } \\
\text { (Sig.) }\end{array}$} \\
\hline & & Mean \pm SD & Median (Range) & & \\
\hline $\mathrm{AA}$ & 7 & $17.10 \pm 4.33$ & $17.4(8-21)$ & \multirow{3}{*}{0.112} & \multirow{3}{*}{$\begin{array}{c}0.946 \\
(\mathrm{NS})\end{array}$} \\
\hline $\mathrm{CC}$ & 15 & $18.47 \pm 15.02$ & $11.3(7-65)$ & & \\
\hline $\mathrm{AC}$ & 25 & $16.10 \pm 6.58$ & $16.3(4-28)$ & & \\
\hline
\end{tabular}

$\chi^{2}$ Kruskal Wallis H test. $\mathbf{p}<0.05$ is significant. Sig.: significance. 